\title{
TAL1 Gene
}

National Cancer Institute

\section{Source}

National Cancer Institute. TAL1 Gene. NCI Thesaurus. Code C18301.

This gene plays a role in regulation of transcription and cell organization. It is involved in both embryonic hematopoiesis and adult erythropoiesis. 